\title{
PENGARUH PROGRAM KESELAMATAN KERJA TERHADAP PRODUKTIVITAS KERJA KARYAWAN PT. MUSI BANYUASIN INDAH
}

\author{
Usailan Oemar \\ Rully Alamsyah \\ Rio Riansyah \\ Sekolah Tinggi Ilmu Ekonomi Rahmaniyah \\ Email: \\ elanoemar11@yahoo.com \\ rullyalamsyah77@gmail.com \\ rio.riansyah95@gmail.com
}

\begin{abstract}
This study aims to determine the effect of work safety programs on employee productivity at PT. Musi Banyuasin Indah. The method in this research is simple linear regression model. The population in this study all employees of PT Musi Banyuasin Indah which amounted to 578 people. The sample in this study amounted to 86 respondents taken using random sampling. The data studied is employee questionnaire data of PT Musi Banyuasin Indah. The results of this study can be seen that there is a significant influence between the safety program on employee work productivity PT. Musi Banyuasin Indah. The result of kofisien termination obtained by value of $R$ square (R2) equal to 0,312 or $31,2 \%$. This means the work safety program affecting work productivity by $31.2 \%$, the remaining $68.8 \%$ influenced by other variables/factors not included/investigated in this study.
\end{abstract}

Keywords : work safety program, productivity, simple linear regression.

\section{PENDAHULUAN}

\section{Latar Belakang Masalah}

Keselamatan Kerja adalah suatu program yang dibuat pekerja maupun pengusaha sebagai upaya mencegah timbulnya kecelakaan akibat kerja dan penyakit akibat kerja dengan cara mengenali hal yang berpotensi menimbulkan kecelakaan akibat kerja serta tindakan antisipatif apabila terjadi kecelakaan akibat kerja. Tujuannya adalah untuk menciptakan tempat kerja yang nyaman sehingga dapat menekan serendah mungkin resiko kecelakaan.

Keselamatan kerja merupakan hal yang penting secara ekonomi, moral, dan hukum, keselamatan kerja telah menjadi isu penting. Moenir (2010: 201) menjelaskan bahwa keselamatan kerja adalah suatu keadaan dalam lingkungan atau tempat kerja yang dapat menjamin secara maksimal keselamatan orang-orang yang berada didaerah atau tempat tersebut baik orang tersebut pegawai ataupun bukan pegawai dari organisasi kerja itu. Perusahaan sedang berusaha untuk tetap menguntungkan dalam ekonomi global yang semakin kompetitif, untuk ini perusahaan menerapkan keselamatan kerja agar praktik bisnis tetap berjalan dengan baik. Bagi banyak perusahaan besar program keselamatan kerja merupakan bentuk perlindungan kelangsungan hidup pekerjanya. 
Persaingan industri yang semakin kompetitif menuntut perusahaan lebih mengoptimalkan seluruh sumber daya yang dimilikinya, secara garis besar sumber daya yang dimilikinya. Sumber daya yang dimiliki perusahaan terbatas jumlahnya, maka perusahaan dituntut mampumemberdayakan dan mengoptimalkan untuk mencapai tujuan perusahaan. Sumber Daya Manusia (SDM) menempati tempat strategis dan penting diantara sumber daya lainnya

SDM yang handal dan tangguh dibutuhkan dalam menunjang bisnis perusahaan agar dapat bersaing, oleh karena itu suatu perusahaan dituntut untuk mampu meningkatkan produktivitas sumber daya manusia yang ada. Produktivitas sumber daya manusia ditentukan oleh sejauh mana sistem yang ada di perusahaan mampu menunjang dan memuaskan keinginan seluruh pihak.

Menurut Yuniarsih dan Suwatno (2008: 157) produktivitas kerja adalah hasil konkrit (produk) yang dihasilkan oleh individu atau kelompok, selama satuan waktu tertentu dalam suatu waktu tertentu dalam suatu proses kerja. Naiknya produksi tidaklah selalu diikuti oleh naiknya produktivitas, karena produksi sebagai aktivitas untuk menghasilkan barang atau jasa memerlukan masukan yang berkenaan dengan efisiensi penggunaan sumber-sumber dalam menghasilkan barang atau jasa, oleh karena itu bertambah besarnya produksi tidaklah selalu berarti bahwa produktivitasnya naik. Keselamatan kerja para karyawan perlu juga diperhatikan, agar mereka terus dapat meningkatkan dan menjaga kualitas dan kuantitas kinerja mereka bagi perusahaan.

Keselamatan kerja tinggi akan menekan tingkat kecelakaan yang menyebabkan sakit, cacat, dan kematian dapat ditekan sekecil mungkin. Keselamatan kerja rendah maka akan berpengaruh buruk terhadap kesehatan sehingga berakibat pada produktivitas yang menurun.

PT. Musi Banyuasin Indah merupakan salah satu perusahaan pabrik yang memproduksi minyak sawit dimana dalam perkembangannya perusahaan ini berkembang maju cukup pesat. PT. Musi Banyuasin Indah dalam proses produksinya menggunakan bahan yang kompleks serta peralatan dengan tingkat teknologi yang semakin tinggi walaupun demikian resiko kecelakaan kerja masih ada. Karyawan PT. Musi Banyuasin Indah, terutama pemanen sawit dalam kegiatannya adalah orang yang paling membutuhkan jaminan keselamatan kerja karena kondisi tempat kerja mereka yang berisiko mengalami kecelakaan kerja, seperti terjatuh, tertimpa benda, terpeleset, terbentur, dan terkena arus listik. Berdasarkan data PT. Musi Banyuasin Indah jumlah kasus dalam satu tahun yaitu tahun 2016 cukup tinggi yaitu ada 19 kasus kecelakaan kerja dengan kategori kecelakaan kerja yang beragam.

Berdasarkan fakta diatas, peneliti ingin melihat juga apakah program keselamatan kerja di PT. Musi Banyuasin Indah telah di terapkan dengan maksimal atau belum. Selain itu dengan banyaknya jumlah kecelakan kerja tersebut membuat karyawan lebih berhatihati bahkan ada juga yang takut untuk melaksanakan pekerjaan yang mempunyai resiko yang kecelakaan kerja yang tinggi. Hal tersebut secara tidak langsung membuat produktivitas kerja juga menurun. Selain itu ketika seorang karyawan mengalami kecelakaan kerja, dia tidak bisa bekerja selama pemulihan. Pekerjaan yang seharusnya dia selesaikan tidak dapat dilaksanakan sehingga membuat pekerjaan tersebut dilaksanakan ketika ia sembuh ataupun diserahkan kepada orang lain. Kondisi tersebut juga berdampak pada penurun produktivitas kerja karyawan tersebut juga berdampak pada produktivitas kerja perusahaan juga menurun.

Berdasarkan latar belakang yang telah dijelaskan diatas maka Peneliti tertarik untuk melakukan penelitian dengan judul: "Pengaruh Program Keselamatan Kerja terhadap Produktivitas Kerja Karyawan pada PT. Musi Banyuasin Indah". 


\section{Rumusan Masalah}

Berdasarkan uraian diatas dapat dirumuskan masalah dalam peneltian ini adalah bagaimana pengaruh program keselamatan kerja terhadap produktivitas kerja karyawan pada PT. Musi Banyuasin Indah.

\section{Tujuan Penelitian}

Adapun tujuan dari penelitian ini adalah untuk mengetahui seberapa besar pengaruh program keselamatan kerja terhadap produktivitas kerja karyawan pada PT. Musi Banyuasin Indah.

\section{Manfaat Penelitian}

Adapun manfaat dari penelitian ini yaitu

1. Manfaat Teoritis

Penelitian ini diharapkan dapat memperluas wawasan, ilmu pengetahuan terutama mengenai manajemen sumber daya manusia khususnya mengenai program keselamatan dan produktivitas kerja.

2. Manfaat Praktis

Memberikan masukan kepada PT. Musi Banyuasin Indah dalam meningkatkan produktivitas kerja serta menjadi bahan pertimbangan dalam kebijakan program keselamatan kerja.

\section{KAJIAN PUSTAKA}

\section{Pengertian Keselamatan Kerja}

Moenir (2010: 201) menjelaskan bahwa keselamatan kerja adalah suatu keadaan dalam lingkungan atau tempat kerja yang dapat menjamin secara maksimal keselamatan orang-orang yang berada didaerah atau tempat tersebut baik orang tersebut pegawai ataupun bukan pegawai dari organisasi kerja itu.

Menurut Mangkunegara (2011: 161), "Keselamatan kerja menunjukkan pada kondisi yang aman atau selamat dari penderitaan, kerusakan atau kerugian di tempat kerja".

\section{Indikator Keselamatan Kerja}

Menurut Moenir (2010: 203) indikator keselamatan kerja adalah sebagai berikut:

\section{Secara Fisik}

Secara fisik, upaya-upaya yang perlu dilakukan perusahaan untuk meningkatkan keselamatan kerja adalah:

a. Penempatan benda atau barang dilakukan dengan diberi tanda-tanda, batas-batas, dan peringatan yang cukup.

b. Penyediaan perlengkapan yang mampu untuk digunakan sebagai alat pencegahan, pertolongan dan perlindungan. Perlengkapan pencegahan misalnya: alat pencegahan kebakaran, pintu darurat, kursi pelontar bagi penerbangan pesawat tempur, pertolongan apabila terjadi kecelakaan seperti: alat PPPK, perahu penolong di setiap kapal besar, tabung oksigen, ambulance dan sebagainya.

2. Secara Sosial Psikologis 
Sedangkan jaminan kecelakaan kerja secara psikologis dapat dilihat pada aturan organisasi sepanjang mengenai berbagai jaminan organisasi atas pegawai atau pekerja yang meliputi:

a. Aturan mengenai ketertiban organisasi atau pekerjaan hendaknya diperlakukan secara merata kepada semua pegawai tanpa kecuali. Masalah-masalah seperti itulah yang sering menjadi sebab utama kegagalan pegawai termasuk para aksekutif dalam pekerjaan. Kegagalan para pegawai dan eksekutif dalam pekerjaan disebabkan oleh kekurangan keahlian.

b. Perawatan dan pemeliharaan asuransi terhadap para pegawai yang melakukan pekerjaan berbahaya dan resiko, yang kemungkinan terjadi kecelakaan kerja yang sangat besar. Asuransi meliputi jenis dan tingkat penderitaan yang dialami pada kecelakaan. Adanya asuransi jelas menimbulkan ketenangan pegawai dalam bekerja.

\section{Tujuan Keselamatan Kerja}

Tujuan keselamatan kerja menurut pendapat Suma'mur (2009:1) adalah sebagai berikut:

1. Melindungi tenaga kerja atas keselamatannya dalam melaksanakan pekerjaan untuk kesejahteraan hidup dan meningkatkan produksi serta produk nasional.

2. Menjamin keselamatan setiap orang lain yang berada di tempat kerja.

3. Sumber produksi dipelihara dan dipergunakan secara aman dan efisien.

\section{Penyebab Utama Timbulnya Kecelakaan Kerja}

Mangkunegara (2011:163) beberapa sebab yang memungkinkan terjadinya kecelakaan yaitu:

1. Keadaan Tempat Lingkungan Kerja

a. Penyusunan dan penyimpangan barang-barang berbahaya kurang diperhitungkan keamanannya

b. Ruang kerja yang terlalu padat dan sesak

c. Pembuangan kotoran dan limbah yang tidak pada tempatnya

2. Pengaturan Udara

a. Pergantian udara di ruang kerja yang tidak baik (ruang kerja yang kotor, berdebu, dan berbau tidak enak).

b. Suhu udara yang tidak dikondisikan pengaturannya.

3. Pengaturan Penerangan

a. Pengaturan dan penggunaan sumber cahaya yang tidak tepat

b. Ruang kerja yang kurang cahaya, remang-remang

4. Pemakaian Peralatan Kerja.

a. Pengamanan peralatan kerja yang sudah usang atau rusak.

b. Penggunaan mesin, alat elektronik tanpan pengaman yang baik.

5. Kondisi fisik dan mental pegawai

a. Kerusakan alat indera, stamina karyawan yang tidak stabil

b. Emosi karyawan yang tidak stabil, kepribadian karyawan yang rapuh, cara berpikir dan kemampuan persepsi yang lemah, motivasi kerja rendah, sikap karyawan yang ceroboh, kurang cermat, dan kurang pengetahuan dalam penggunaan fasilitas kerja terutama fasilitas kerja yang membawa resiko bahaya.

\section{Pengertian Produktivitas Kerja}

Menurut Yuniarsih dan Suwatno (2008: 157) produktivitas kerja adalah hasil konkrit (produk) yang dihasilkan oleh individu atau kelompok, selama satuan waktu tertentu dalam suatu waktu tertentu dalam suatu proses kerja. Riyanto (2011 :22) juga 
berpendapat bahwa produktivitas kerja adalah perbandingan antara hasil yang dicapai dengan peran tenaga kerja persatuan waktu.

Dari pengertian diatas dapat disimpulkan bahwa produktivitas kerja adalah kemampuan karyawan dalam berproduksi dibandingkan dengan input yang digunakan.

\section{Indikator Produktivitas Kerja}

Menurut Riyanto (2011: 24) produktivitas kerja mempunyai indikator sebagai berikut:

1. Tingkat absensi tinggi

Tinggi rendahnya tingkat absensi dari pegawai yang ada akan langsung berpengaruh terhadap produktivitas, karena pegawai yang tidak masuk kerja tidak akan produktif, dengan demikian hasil produksinya rendah yang akhirnya target produksi yang telah ditetapkan tidak tercapai.

2. Tingkat perolehan hasil

Telah dijelaskan di atas bahwa produktivitas adalah kemampuan seseorang dalam menghasilkan barang atau jasa. Berdasarkan dari pendapat tersebut dengan adanya produktivitas kerja pegawai rendah otomatis hasil produksi barang atau jasa akan menurun sehingga target produksi tidak tercapai.

3. Kualitas yang dihasilkan

Dalam kegiatan menghasilkan produk perusahaan berusaha agar produk tersebut mempunyai kualitas yang baik, karena apabila produk yang dihasilkan kurang baik maka produktivitas karyawan akan menurun.

4. Tingkat kesalahan

Salah satu penyebab dari turunnya produktivitas pegawai dalam menghasilkan produk adalah tingkat kesalahan, karena apabila tingkat kesalahan tinggi, maka produktivitas akan rendah.

5. Waktu yang dibutuhkan

Kegiatan proses produksi memerlukan waktu yang cukup, karena apabila waktu yang diberikan untuk menghasilkan produk kurang yang dihasilkan juga sedikit, sehingga target produksi tidak tercapai.

\section{Sumber-Sumber Produktivitas Kerja} berikut:

Sumber-sumber produktivitas menurut Nawawi (2008: 103) adalah sebagai

1. Penggunaan pikiran

Produktivitas kerja dikatakan tinggi apabila untuk memperoleh hasil yang maksimal dipergunakan cara berkerja yang paling mudah.

2. Penggunaan tenaga jasmani

Produktivitas dikatakan tinggi bilamana mengerjakan sesuatu diperoleh hasil dan jumlahnya terbanyak dan mutu terbaik dengan tidak banyak menggunakan tenaga jasmani atau rohani.

3. Penggunaan waktu

Semakin singkat jangka waktu yang dipergunakan untuk mencapai hasil terbanyak dan terbaik, menunjukkan semakin produktif pelaksanaan suatu pekerjaan.

4. Penggunaan ruangan

Pekerjaan akan produktif apabila sejumlah personil yang bekerja sama dalam melaksanakan pekerjaan ditempatkan dalam suatu ruangan yang berdekatan jaraknya untuk mondar-mandir lebih hemat.

5. Penggunaan material atau bahan

Suatu pekerjaan dikatakan produktif apabila penggunaan bahan atau material dan peralatannya tidak terlalu banyak yang terbuang dan harganya tidak terlalu mahal. 


\section{Karakter Karyawan yang mempunyai Produktivitas Kerja Tinggi}

Gaspersz dalam Sutrisno (2010: 71) mengemukakan karakteristik umum dari individu atau karyawan yang produktif biasanya ditandai dengan beberapa hal berikut:

1. Secara terus menerus selalu mencari berbagai gagasan dan cara penyelesaian tugas yang lebih baik.

2. Selalu memberikan saran-saran untuk perbaikan secara sukarela

3. Menggunakan waktu secara efekif dan efisien

4. Selalu melakukan perencanaan dengan menyertakan jadwal waktu

5. Selalu bersikap positif terhadap pekerjaannya

6. Dapat berperan sebagai anggota tim kerja sama dengan baik, sebagimana juga menjadi pemimpin tim kerja sama dengan baik.

7. Dapat memotovasi diri melalui dorongan dari dalam diri sendiri

8. Memiliki pengetahuan dan pemahaman yang baik terhadap pekerjaannya serta mau menerapkannya dalam pekerjaan itu.

9. Mau menerima ide-ide atau saran-saran yang dianggap lebih baik dari orang lain.

\section{Kerangka Pemikiran}

Kerangka pemikiran menyajikan hubungan antara dua variabel berikut yang dijelaskan dengan gambar secara rinci mengenai variabel-variabel yang diteliti tersebut. Berikut ini adalah kerangka pemikiran dari penelitian ini:

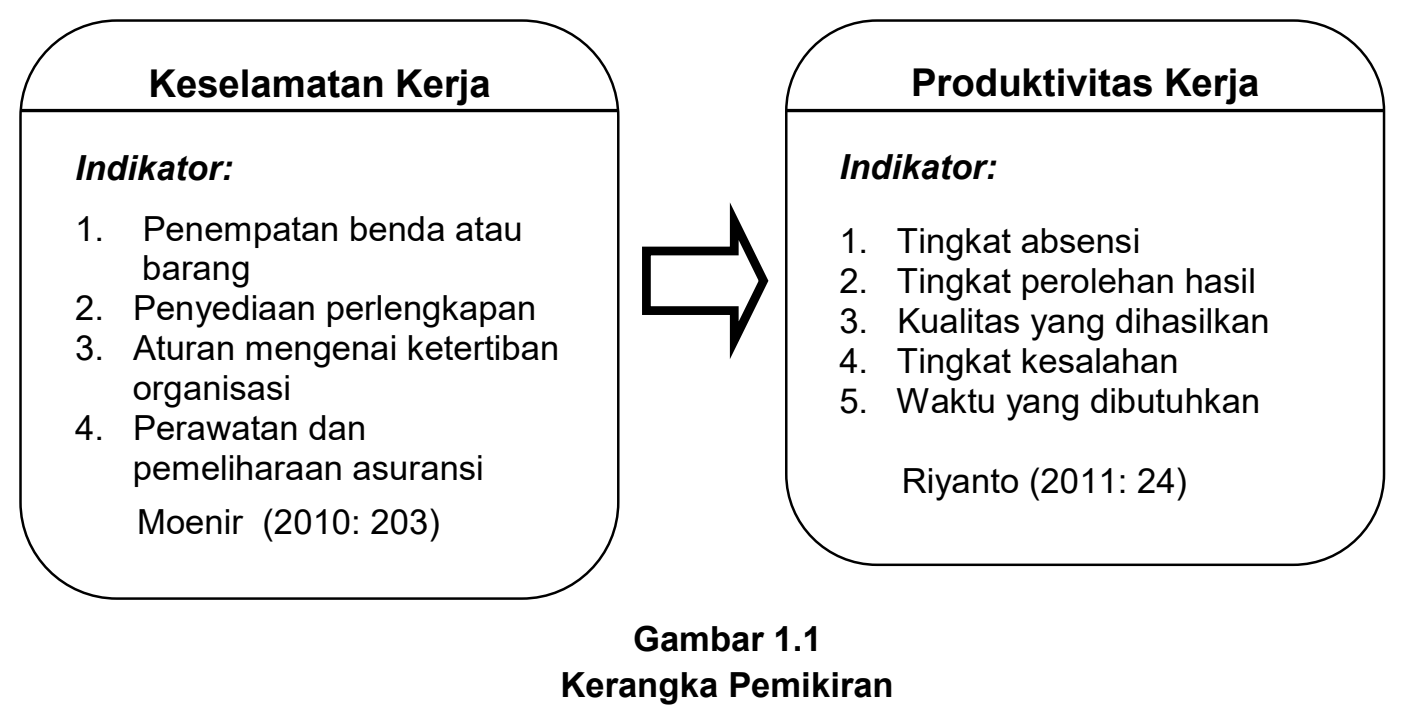

\section{Hipotesis Penelitian}

Berdasarkan latar belakang yang telah penulis uraian diatas, maka hipotesis dalam penelitian ini adalah:

Ho : Program keselamatan kerja tidak berpengaruh signifikan terhadap produktivitas kerja karyawan pada PT. Musi Banyuasin Indah.

Ha : Program keselamatan kerja berpengaruh signifikan terhadap produktivitas kerja karyawan pada PT. Musi Banyuasin Indah.

\section{Metodologi Penelitian}

\section{Lokasi dan Waktu Penelitian}

Penelitian dilaksanakan pada PT. Musi Banyuasin Indah yang berlokasi di Jalan Selabu Kecamatan Batanghari Leko Kabupaten Musi Banyuasin. 


\section{Metode Penelitian}

Metode penelitian yang digunakan dalam penelitan ini adalah metode kuantitatif. Arikunto (2010: 42) metode penelitian kuantitatif menggunakan strategi penelitian seperti seperti eksperimen dan survei yang memerlukan data statistik.

\section{Populasi, Sampel dan Teknik Sampling}

\section{Populasi}

Menurut Arikunto (2010: 108), "Populasi adalah keseluruhan subjek penelitian" Populasi dalam penelitian ini adalah seluruh karyawan pada PT. Musi Banyuasin Indah yang berjumlah 578 orang.

\section{Sampel.}

Arikunto (2010: 131) mengemukakan bahwa sampel adalah sebagian dari populasi yang diteliti. Sugiyono (2009: 149) mengatakan, perhitungan menggunakan teknik Slovin dengan kesalahannya 10\%, sebagai berikut:

$$
\begin{aligned}
\mathrm{n} & =\frac{N}{1+N e^{2}} \\
& =\frac{578}{1+578(0,10)^{2}}=\frac{578}{1+578(0,01)} \\
& =\frac{578}{6,78}=85,52(86 \text { responden })
\end{aligned}
$$

\section{Dimana}

$$
\begin{aligned}
\mathrm{n} & =\text { jumlah sampel } \\
\mathrm{N} & =\text { jumlah populasi } \\
\mathrm{e} & =\text { batas toleransi kesalahan (error tolerence) }
\end{aligned}
$$

Berdasarkan perhitungan dengan menggunakan teknik slovin diatas diperoleh bahwa sampel dalam penelitian ini berjumlah 86 responden.

\section{Teknik Sampling}

Penetapan sampel diambil secara proporsional setidaknya memperhatikan besaran atau banyaknya jumlah populasi. Maka pengambilan sampel biasanya menggunakan persentase.

Dalam penelitian ini jumlah sampelnya adalah 86 responden karena penelitian ini mempunyai 5 bagian maka diambil secara proporsional yaitu, pada bagian supervisor sortase yang terdapat 143 karyawan diambil 21 responden, pada bagian supervisor maintance terdapat 125 karyawan diambil 19 responden, pada bagian supervisor proses terdapat 102 karyawan diambil 15 responden, pada bagian supervisor logistiker terdapat 98 karyawan diambil 15 responden, dan pada bagian asisten supervisor terdapat 110 karyawan diambil 16 responden.

\section{Teknik Pengumpulan Data}

Metode pengumpulan data yang penulis lakukan dalam penulisan penelitian ini, menurut Arikunto (2010: 256) adalah: 
1. Teknik Observasi, yaitu kegiatan yang dilakukan dengan cara melakukan pengamatan langsung terhadap objek penelitian.

2. Metode angket (Kuesioner) Kuesioner adalah sejumlah pertanyaan tertulis yang digunakan untuk memperoleh informasi dari responden dalam arti laporan tentang pribadinya atau hal-hal yang ia ketahui.

3. Metode dokumentasi adalah mencari data mengenai hal-hal atau variabel yang berupa catatan, transkrip, buku, surat kabar, majalah, prasasti, notulen rapat, agenda dan sebagainya.

\section{Teknik Analisis Data}

Setelah teknik pengumpulan data dilakukan, selanjutnya adalah melakukan pengelolahan data. Teknik pengolahan data dalam penelitian ini menggunakan bantuan program SPSS versi 16.

Adapun tahapan analisis kuantitatif yang digunakan untuk menganalisis data dalam penelitian ini adalah :

1. Uji Validitas

Validitas instrumen berhubungan dengan kesesuaian dan ketepatan fungsi alat ukur yang digunakan. Maka dari itu sebelum sebuah instrumen digunakan perlu adanya pengujian validitas terhadap instrumen tersebut. uji validitas adalah prosedur untuk memastikan apakah kuesioner yang digunakan valid atau tidak.

Dengan kriteria:

- jika $\mathrm{r}$ hitung $>\mathrm{r}$ tabel dengan tingkat signifikansi sebesar 5\% maka item kuesioner penelitian dapat dikatakan valid atau layak dijadikan item pertanyaan dalam penelitan.

- jika $r$ hitung $<\mathrm{r}$ tabel dengan tingkat signifikansi sebesar 5\% maka item kuesioner penelitian dapat dikatakan tidak valid atau tidak layak dijadikan item pertanyaan dalam penelitan.

2. Uji Reliabilitas

Arikunto (2010: 154) menjelaskan bahwa pengertian reliabilitas adalah suatu instrumen cukup dapat dipercaya untuk digunakan sebagai alat pengumpul data karena istrumen tersebut sudah baik.

Uji reliabilitas digunakan untuk mengetahui konsistensi alat ukur, apakah alat ukur yang digunakan dapat diandalkan dan tetap konsisten jika dilakukan pengukuran berulang. Instumen dapat dikatakan reliabel jika nilai Cronbach Alpha lebih besar dari 0,60 .

3. Analisis Regresi

Dalam penelitian ini analisis regresi yang digunakan adalah analisis regresi sederhana. Analisis regresi sederhana untuk mengetahui pengaruh dari variabel bebas terhadap variabel terikat atau dengan kata lain untuk mengetahui seberapa jauh perubahan variabel bebas dalam mempegaruhi variabel terikat.

Adapun persamaan untuk analisis regresi sederhana adalah sebagai berikut:

$$
\mathbf{Y}=\mathbf{a}+\mathbf{b X}+\mathbf{e}
$$

Dimana :

$$
\begin{aligned}
& \mathrm{Y}=\text { Produktivitas Kerja } \\
& \mathrm{a}=\text { Konstanta }
\end{aligned}
$$


$\mathrm{b}=$ Koefisien regresi

$\mathrm{X}=$ Keselamatan Kerja

$\mathrm{e}=$ standard error

4. Analisis Korelasi

Analisis korelasi sederhana (Bivariate Correlation) digunakan untuk mengetahui keeratan hubungan antara dua variabel dan untuk mengetahui arah hubungan yang terjadi. Tingkat hubungan tersebut dapat dibagi menjadi tiga kriteria, yaitu mempunyai hubungan positif, mempunyai hubungan negatif, dan tidak mempunyai hubungan.

Menurut Sugiyono (2009: 265), pedoman untuk memberikan interprestasi koefisien korelasi sebagai berikut :

- $0,00-0,199=$ sangat rendah

- $0,20-0,399=$ rendah

- $0,40-0,599=$ sedang

- $0,60-0,799=$ kuat

- $0,80-1,000=$ sangat kuat

5. Uji Hipotesis

Dalam melakukan uji hipotesis dalam penelitian ini menggunakan uji t. Uji t pada dasar menunjukkan seberapa jauh pengaruh satu variabel independen mempengaruhi variabel dependen.

Dengan dasar pengambilan keputusan :

- Jika probabilitas (signifikansi) $>0,05(\alpha)$ atau T hitung $<\mathrm{T}$ tabel berarti hipotesis tidak terbukti maka Ho diterima dan Ha di tolak.

- Jika probabilitas (signifikansi) $<0,05(\alpha)$ atau T hitung $>\mathrm{T}$ tabel berarti hipotesis tidak terbukti maka Ho ditolak dan Ha diterima.

\section{PEMBAHASAN}

\section{Karakteristik Responden}

Dalam karakteristik responden ini akan disajikan data yang diperoleh dari penelitian yang telah dilakukan. Pengumpulan data ini dilakukan dengan cara penyebaran kuesioner kepada 86 orang responden yang merupakan karyawan pada PT. Musi Banyuasin Indah. Dalam karakterisitik responden ini akan disajikan data mengenai jenis kelamin, usia, masa kerja, status pernikahan. Berikut merupakan karakteristik responden tersebut:

Tabel 1.

Distribusi Karekteristik Responden

\begin{tabular}{|c|c|c|c|}
\hline \multicolumn{2}{|l|}{ Keterangan } & Jumlah & $\%$ \\
\hline \multirow{3}{*}{$\begin{array}{l}\text { Jenis } \\
\text { Kelamin }\end{array}$} & Laki-laki & 84 & 97,67 \\
\hline & Perempuan & 2 & 2,33 \\
\hline & Jumlah & 86 & 100 \\
\hline \multirow{4}{*}{$\begin{array}{l}\text { Usia } \\
\text { Responden }\end{array}$} & $<31$ Tahun & 35 & 40,70 \\
\hline & 31-40 Tahun & 30 & 34,88 \\
\hline & $>40$ Tahun & 21 & 24,42 \\
\hline & Jumlah & 86 & 100 \\
\hline \multirow{2}{*}{$\begin{array}{l}\text { Masa Kerja } \\
\text { Responden }\end{array}$} & $<5$ tahun & 40 & 46,51 \\
\hline & 5 - 10 tahun & 32 & 37,21 \\
\hline
\end{tabular}




\begin{tabular}{|l|l|l|l|}
\hline & $>10$ tahun & 14 & 16,28 \\
\cline { 2 - 4 } & Jumlah & $\mathbf{8 6}$ & $\mathbf{1 0 0}$ \\
\hline \multirow{3}{*}{$\begin{array}{l}\text { Status } \\
\text { Pernikahan }\end{array}$} & Menikah & 58 & 67,44 \\
\cline { 2 - 4 } & Belum Menikah & 28 & 32,56 \\
\cline { 2 - 4 } & Jumlah & $\mathbf{8 6}$ & $\mathbf{1 0 0}$ \\
\hline
\end{tabular}

Sumber : data kuesioner yang telah diolah, 2017

Dari tabel. 1 dapat kita lihat, bahwa responden yang berjenis kelamin pria berjumlah 84 responden $(97,67 \%)$ dan responden berjenis kelamin wanita 2 responden $(2,33 \%)$. Rresponden yang berusia dibawah di bawah 31 tahun berjumlah 35 responden (40,70\%), 31 hingga 40 tahun berjumlah 30 responden $(34,88 \%)$, dan diatas 40 tahun berjumlah 21 responden $(24,42 \%)$, responden yang mempunyai masa kerja dibawah 5 tahun berjumlah 40 responden $(46,51 \%)$, responden yang mempunyai masa kerja 5 hingga 10 tahun berjumah 32 responden $(37,21 \%)$ dan responden yang mempunyai masa kerja lebih dari 10 tahun berjumlah 14 responden $(16,28 \%)$,responden yang sudah menikah berjumlah 58 responden $(67,44 \%)$, respoden yang belum menikah berjumlah 28 responden $(32,56 \%)$.

\section{Distribusi Jawaban Kuesioner}

Berdasarkan jawaban kuesioner diketahui bahwa untuk pernyataan pertama mengenai tingkat kehadiran saya bekerja memenuhi standar, mendapatkan jawaban dari responden yang sangat setuju ada 55 responden $(63,85 \%)$, responden yang menyatakan setuju ada 29 responden $(33,72,24 \%)$, responden yang menyatakan ragu-ragu ada 1 responden $(1,16 \%)$, dan responden yang menyatakan tidak setuju ada $1(1,16 \%)$.

Pada pernyataan kedua mengenai saya tetap bekerja walaupun mempunyai kepentingan pribadi yang penting, mendapatkan jawaban dari responden yang sangat setuju ada 46 responden $(53,49 \%)$, responden yang menyatakan setuju ada 38 responden $(44,19 \%)$, responden yang menyatakan ragu-ragu ada 1 responden $(1,16 \%)$, dan responden yang menyatakan tidak setuju ada $1(1,16 \%)$.

Pada pernyataan ketiga mengenai saya mempunyai kemampuan bekerja dengan hasil yang maksimal, mendapatkan jawaban dari responden yang sangat setuju ada 47 responden $(54,65 \%)$, responden yang menyatakan setuju ada 37 responden $(43,02 \%)$, dan responden yang menyatakan ragu-ragu ada 1 responden $(1,16 \%)$.

Pada pernyataan keempat mengenai hasil kerja saya sudah memenuhi target yang telah ditetapkan perusahaan mendapatkan jawaban dari responden yang sangat setuju ada 51 responden $(59,30 \%)$, responden yang menyatakan setuju ada 33 responden $(38,37 \%)$, responden yang menyatakan ragu-ragu ada 1 responden $(1,16 \%)$, dan responden yang menyatakan tidak setuju ada $1(1,16 \%)$.

Pada pernyataan kelima mengenai pekerjaan yang saya lakukan merupakan hasil terbaik dan cepat, mendapatkan jawaban dari responden yang sangat setuju ada 53 responden $(61,53 \%)$, responden yang menyatakan setuju ada 32 responden $(37,21 \%)$, dan responden yang menyatakan ragu-ragu ada 1 responden $(1,16 \%)$.

Pada pernyataan keenam mengenai kualitas kerja yang saya hasilkan sudah memenuhi standar yang ditetapkan perusahaan, mendapatkan jawaban dari responden yang sangat setuju ada 53 responden $(61,63 \%)$, responden yang menyatakan setuju ada 32 responden $(37,21 \%)$, dan responden yang menyatakan ragu-ragu ada 1 responden $(1,16 \%)$.

Pada pernyataan ketujuh mengenai saya mampu bekerja dengan tingkat kesalahan yang kecil, mendapatkan jawaban dari responden yang sangat setuju ada 44 responden $(51,16 \%)$, responden yang menyatakan setuju ada 40 responden $(46,51 \%)$, dan responden yang menyatakan ragu-ragu ada 1 responden $(1,16 \%)$.

Pada pernyataan kedelapan mengenai tingkat kesalahan saya dalam bekerja tidak membuat kerugian yang besar bagi perusahaan, mendapatkan jawaban dari responden yang 
sangat setuju ada 50 responden $(58,14 \%)$, responden yang menyatakan setuju ada 35 responden $(40,70 \%)$, dan responden yang menyatakan ragu-ragu ada 1 responden $(1,16 \%)$.

Pada pernyataan kesembilan mengenai saya memerlukan waktu yang singkat untuk menyelesaikan pekerjaan saya, mendapatkan jawaban dari responden yang sangat setuju ada 51 responden $(59,30 \%)$, responden yang menyatakan setuju ada 34 responden $(39,53 \%)$, dan responden yang menyatakan ragu-ragu ada 1 responden $(1,16 \%)$. Pada pernyataan kesepuluh mengenai dengan waktu yang singkat dalam menyelesaikan pekerjaan membuat produktivitas kerja saya menjadi meningkat, mendapatkan jawaban dari responden yang sangat setuju ada 47 responden $(54,65 \%)$, responden yang menyatakan setuju ada 38 responden $(44,19 \%)$, dan responden yang menyatakan ragu-ragu ada 1 responden $(1,16 \%)$.

\section{Analisis Data}

\section{Analisis Regresi}

Analisis regresi digunakan untuk melihat pengaruh variabel bebas terhadap variabel terikat. Dalam analisis regresi variabel bebas berfungsi untuk menerangkan sedangkan variabel terikat berfungsi sebagai yang diterangkan. Dalam penelitian ini hanya terdapat variabel satu variabel $\mathrm{X}$ sehingga digunakan analisis regresi sederhana. Hasil penghitungan diperoleh koefisien regresi dan nilai konstanta seperti pada tabel berikut:

Tabel 2

Nilai Koefisien Regresi

Coefficients $^{\mathrm{a}}$

\begin{tabular}{|c|c|c|c|c|c|c|}
\hline \multirow{2}{*}{\multicolumn{2}{|c|}{ Model }} & \multicolumn{2}{|c|}{ Unstandardized Coefficients } & \multirow{2}{*}{$\begin{array}{c}\begin{array}{c}\text { Standardized } \\
\text { Coefficients }\end{array} \\
\text { Beta }\end{array}$} & \multirow[b]{2}{*}{$\mathrm{t}$} & \multirow[b]{2}{*}{ Sig. } \\
\hline & & B & Std. Error & & & \\
\hline 1 & (Constant) & 22.254 & 3.791 & & 5.870 & .000 \\
\hline & $\mathrm{X}$ & .635 & .103 & .558 & 6.167 & .000 \\
\hline
\end{tabular}

a. Dependent Variable: Y

Sumber: data primer yang telah diolah 2017

Dari perhitungan dengan menggunakan SPSS versi 16 diatas dapat dibuat sebuah persamaan regresi yaitu sebagai berikut :

$$
Y=22,544+0,635 X
$$

Keterangan :

$\mathrm{Y}=$ Produktivitas kerja

$\mathrm{a}=$ Konstanta

$\mathrm{b}=$ Koefesien regresi

$\mathrm{X}=$ Keselamatan Kerja

Interprestasi hasil persamaan di atas sebagai berikut

a. Nilai konstanta sebesar 22,544 menyatakan bahwa jika keselamatan kerja (X) nilainya adalah 0 , maka produktivitas kerja (Y) nilainya adalah 22,544. 
b. Koefesien regresi untuk produktivitas kerja (Y) sebesar 0,635 menyatakan bahwa setiap penambahan satu nilai keselamatan kerja $(\mathrm{X})$, maka nilai produktivitas kerja $(\mathrm{Y})$ bertambah sebesar 0,635 .

\section{Analisis Korelasi}

Analisis korelasi dalam penelitian ini bertujuan untuk mengetahui seberapa besar pengaruh keselamatan kerja terhadap produktivitas kerja. Hasil perhitungan korelasi tersebut tersebut dapat dilihat dari tabel 3. berikut ini:

Tabel 3

Nilai Koefisien Korelasi

Model Summary

\begin{tabular}{|c|r|r|r|r|}
\hline Model & $\mathrm{R}$ & R Square & Adjusted R Square & \multicolumn{2}{|c|}{$\begin{array}{c}\text { Std. Error of the } \\
\text { Estimate }\end{array}$} \\
\hline 1 & $.558^{\mathrm{a}}$ & .312 & .303 & 2.84995 \\
\hline
\end{tabular}

a. Predictors: (Constant), X

Sumber : data primer yang telah diolah, 2017

Dari tabel diatas diketahui nilai korelasi (R) sebesar 0,558, hal ini menunjukkan hubungan yang sedang karena berada di kisaran 0,40-0,599.

Berdasarkan tabel diatas diperoleh hasil perhitungan analisis determinasi diketahui bahwa $R$ square $\left(\mathrm{R}^{2}\right)$ sebesar 0,312 atau sebesar $31,2 \%$. Berarti keselamatan kerja mempengaruhi produktivitas kerja sebesar $31,2 \%$, sisanya $68,8 \%$ dipengaruhi variabel lain yang tidak dimasukan dalam penelitian ini.

\section{Uji Hipotesis (Uji t)}

Hasil perhitungan uji t dapat dilihat dari tabel 4. berikut ini:

Tabel 4.

Coefficients $^{\mathrm{a}}$

\begin{tabular}{|c|c|c|c|c|c|}
\hline \multirow[b]{2}{*}{ Model } & \multicolumn{2}{|c|}{ Unstandardized Coefficients } & $\begin{array}{l}\text { Standardized } \\
\text { Coefficients }\end{array}$ & \multirow[b]{2}{*}{$\mathrm{t}$} & \multirow[b]{2}{*}{ Sig. } \\
\hline & B & Std. Error & Beta & & \\
\hline Constant) & 22.254 & 3.791 & & 5.870 & .000 \\
\hline $\mathrm{X}$ & .635 & .103 & .558 & 6.167 & .000 \\
\hline
\end{tabular}

a. Dependent Variable: $Y$

Berdasarkan hasil uji t diketahui bahwa nilai t-hitung adalah sebesar 6,167 sedangkan t tabel untuk 86 responden yaitu sebesar 1,663. Dari perhitungan tersebut $t$ hitung lebih besar dari t tabel yaitu 6,167 >1,663. Jadi dapat disimpulkan bahwa adanya pengaruh program keselamatan kerja terhadap produktivitas kerja karyawan pada PT. Musi Banyuasin Indah.

\section{SIMPULAN DAN SARAN}

\section{Simpulan}

1. Keselamatan kerja berpengaruh positif terhadap produktivitas kerja berdasarkan hasil perhitungan regresi yaitu $\mathrm{Y}=\mathbf{2 2 , 5 4 4}+\mathbf{0 , 6 3 5 X}$, berarti: 
a. Nilai konstanta sebesar 22,544 menyatakan bahwa jika keselamatan kerja (X) nilainya adalah 0 , maka produktivitas kerja (Y) nilainya adalah 22,544.

b. Koefesien regresi untuk produktivitas kerja (Y) sebesar 0,635 menyatakan bahwa setiap penambahan satu nilai keselamatan kerja $(\mathrm{X})$, maka nilai produktivitas kerja (Y) bertambah sebesar 0,635 .

2. Berdasarkan perhitungan korelasi besar pengaruh kerja $(\mathrm{X})$ terhadap produktivitas kerja (Y) adalah 0,558 yang berarti mempunyai hubungan yang sedang karena berada di kisaran 0,40-0,599.

3. Berdasarkan hasil perhitungan analisis determinasi diketahui $R$ square $\left(\mathrm{R}^{2}\right)$ adalah 0,312 atau $31,2 \%$. Berarti keselamatan kerja mempengaruhi produktivitas kerja sebesar $31,2 \%$, sisanya $68,8 \%$ dipengaruhi variabel lainyang tidak dimasukan dalam penelitian ini.

4. Berdasarkan perhitungan uji t diperoleh 6,167 > 1,663. Maka Ho ditolak dan Ha diterima, berarti ada pengaruh program keselamatan kerja terhadap produktivitas kerja karyawan pada PT. Musi Banyuasin Indah.

\section{Saran}

Setelah penulis melakukan penelitian mengenai pengaruh keselamatan kerja terhadap produktivitas kerja karyawan di PT. Musi Banyuasin Indah, penulis memberikan saran sebagai berikut:

1. Menanggapi masih terjadinya kelalaian dan tindakan pencegahan yang kadang kadang kurang tanggap dalam menjalankan program keselamatan kerja, maka sebaiknya PT. Musi Banyuasin Indah selalu mengadakan Pendidikan dan Pelatihan Keselamatan Kerja secara lebih berkala agar lebih terarah, lebih jelas dan lebih baik lagi guna untuk meminimalisasi tingkat kecelakaan kerja.

2. Jaminan keselamatan karyawan yang sudah ada sekarang ini sebaiknya lebih ditingkatkan lagi, seperti jaminan kepada keluarga karyawan agar karyawan merasa nyaman, aman dan tenang dalam melaksanakan pekerjaan guna mencapai produktivitas kerja karyawan yang efektif dan efisien.

3. Perusahaan harus bisa lebih fokus untuk memperhatikan beberapa alat-alat kerja pendukung proses produksi mengingat PT. Musi Banyuasin Indah dalam proses produksinya banyak mesin-mesin yang cukup berbahaya yang mampu menyebabkan karyawan meninggal seketika.

4. Perusahaan harus meningkatkan produktivitas kerja karyawan dengan mempertimbangkan faktor-faktor lain yang tidak dimasukkan dalam penelitian ini agar perusahaan mencapai target yang telah ditetapkan sebelumnya.

\section{DAFTAR PUSTAKA}

Anonim. 2010. Pedoman Penyusunan Skripsi Sekolah Tinggi Ilmu Ekonomi Rahmaniyah. Sekayu.

Arikunto, Suharsimi. 2010. Manajemen Penelitian. Jakarta: Rineka Cipta.

Buchari. 2007. Penanggulangan Kecelakaan. Organisasi Perburuhan Internasional (ILO) tahun 1962. Klasifikasi menurut jenis kecelakaan. 
Dain, Rakyat. 2014. Sistem Manajemen Keselamatan \& Kesehatan Kerja OHSAS 18001. Jakarta.

Mangkunegara, A.A. Anwar Prabu. 2011. Manajemen Sumber Daya Manusia Perusahaan. Bandung: Rosda.

Moenir, H.AS. 2010. Manajemen Pelayanan Umum di Indonesia. Jakarta: PT. Bumi Aksara.

Muchdarsyah, Sinungan. 2009. Produktivitas Apa Dan Bagaimana. Jakarta: Bumi Aksara.

Nawawi, Hadari. 2008. Manajemen Sumber Daya Manusia Untuk Bisnis yang Kompetitif. Yogyakarta: Gadjah Mada University.

Riyanto, Bambang. 2011. Dasar-Dasar Pembelanjaan Perusahaan. Yogyakarta: BPFE.

Suma'mur, P.K.1989. Keselamatan Kerja dan Pencegahan Kecelakaan Jakarta: CV. Haji Masagung

2009. Keselamatan Kerja dan Pencegahan Kecelakaan. Jakarta: Sagung Seto.

Sugiyono. 2009. Metodelogi Penelitian Bisnis. Edisi Kelima. Bandung: CV. Alfabeta.

Sutrisno, Edy. 2010. Manajemen Sumber Daya Manusia. Jakarta: Prenada Media.

Yuniarsih, Tjutju dan Suwatno. 2008. Manajemen Sumber Daya Manusia. Bandung: Alfabeta. 